Скаб, Марія, і Скаб, Мар'ян. «Сучасний інтелектуальний діалог про релігійність Лесі Українки: „Відкриття старого скарбу для нових людей” (С. Шевчук), або „Розмова в часі, між нею і вами” (О. Забужко)». Лінгвостилістичні студії, вип. 14, 2021, с. 125-34.

Skab, Maria, and Skab, Marian. "Modern Intellectual Dialogue on the Religiosity of Lesya Ukrainka: "Discovery of the Old Treasure for New People" (S. Shevchuk), or "Conversation in Time, Between Her and You" (0. Zabuzhko)”. Linguostylistic Studies, iss. 14, 2021, pp. 125-34.

Удк 811.161.2'38

https://doi.org/10.29038/2413-0923-2021-14-125-134

\title{
СУЧАСНИЙ ІНТЕЛЕКТУАЛЬНИЙ ДІАЛОГ ПРО РЕЛІГІЙНІСТЬ ЛЕСІ УКРАЇНКИ: «ВІДКРИТТЯ СТАРОГО СКАРБУ ДЛЯ НОВИХ ЛЮДЕЙ» (С. ШЕВЧУК), АБО «РОЗМОВА В ЧАСІ, МІЖ НЕЮ І ВАМИ» (0. ЗАБУЖКО)
}

\author{
Марія Скаб \\ Чернівецький національний університет імені Юрія Федьковича, \\ Чернівці, Україна \\ Мар'ян Скаб \\ Чернівецький національний університет імені Юрія Федьковича, \\ Чернівці, Україна
}

У статті проаналізовано чотири розмови про Лесю Українку Предстоятеля Української греко-католицької церкви Святослава Шевчука та письменниці Оксани Забужко, долучені до книги Лесі Українки «Апокриф», і зроблено висновок про появу нового жанру наукового дискурсу - інтелектуального діалогу, якому притаманні надзвичайно високий рівень науковості й сучасні мовностилістичні засоби: інтертекстуальність, використання висловів різними мовами, різноплановість лексики, наявність розмовних складників тощо.

Ключові слова: релігійність, науковий стиль, мовностилістичні засоби.

\section{MODERN INTELLECTUAL DIALOGUE ON THE RELIGIOSITY OF LESYA UKRAINKA: “DISCOVERY OF THE OLD TREASURE FOR NEW PEOPLE” (S. SHEVCHUK), OR “CONVERSATION IN TIME, BETWEEN HER AND YOU” (O. ZABUZHKO)}

\author{
Maria Skab \\ Yuriy Fedkovych Chernivtsi National University, Chernivtsi, Ukraine \\ Marian Skab \\ Yuriy Fedkovych Chernivtsi National University, Chernivtsi, Ukraine
}

The article deals with the analysis of four conversations about Lesya Ukrainka between the Primate of the Ukrainian Greek Catholic Church, His Beatitude Sviatoslav Shevchuk, and the writer Oksana Zabuzhko, attached to Lesya Ukrainka's book "Apocrypha" and devoted to her attitudes to religion. The interlocutors explain the themes of Christology (images of Judas,

(с) Скаб М., Скаб М., Волинський національний університет імені Лесі Українки, 2021.

Це стаття відкритого доступу на умовах CC BY-NC 4.0 
Christ, the cult of martyrdom, sacrifice), Christianity and feminism, the idea of loneliness, which is one of the most important existential themes of modern culture, the role of the prophet in society, the issue of the Church and family, the topic of the lost Ukrainian paganism, etc. and they conclude that Lesya Ukrainka is an apologist for Christianity, but not Christianity as a system of doctrine, of abstract, logical formations, but Christianity as a "living communion with God". Linguistic and stylistic features of the analysed text testify the emergence of a new genre in Ukrainian literature - intellectual dialogue, which is characterized by an extremely high level of scientificity (with a rich use of special narrow metalanguage) and modern linguistic means, including intertextuality (citations of the Holy Scriptures, of Church Fathers' works, of prominent theologians, philosophers, famous modern figures, the use of expressions in different languages (Latin, English, German, Polish, etc.); diversity of vocabulary (Church Slavonic - colloquial vocabulary); application of surzhyk and slang elements in the normalized speech; the presence of spoken intonations; a combination of extreme seriousness with humour (sometimes irony), etc .

Key words: religiosity, scientific style, linguistic and stylistic means.

Вступ. Релігійність Лесі Українки віддавна була предметом дослідження науковців, починаючи ще з радянських часів (Корнейчик), але особливо активно ії студіювали в порадянський час (Бетко, «Біблія»; Мороз; Бетко «Біблійні мотиви»; Заїка; Антофійчук, «Християнські ідеї»; Антофійчук «Християнський контекст»; Гребенюк; Загребельний; Мизак, і Яремчук). Праця, яку ми обрали предметом свого дослідження, вирізняється 3-поміж усіх тим, що це не просто науковий аналіз зголошеної проблеми літературознавцем і богословом, а діалог двох інтелектуалів сучасності. Йдеться про книгу, яка нещодавно вийшла 3 нагоди 150-річного ювілею Лесі Українки в київському видавництві «Комора», - «Апокриф» Лесі Українки, в якій уміщено її твори на сюжети 3 євангельської та ранньохристиянської історії в авторській редакції, написані упродовж 1901-1911 років (апокриф «Що дасть нам силу? », «Лист до А.Кримського» від 27 січня 1906 р., драматичні поеми «Одержима», «Руфін і Прісцілла», «На полі крові», «Йоганна, жінка Хусова», «Адвокат Мартіан»), де текстам Лесі Українки передують чотири розмови про Лесю Українку Предстоятеля Української греко-католицької церкви Блаженнішого Святослава Шевчука та письменниці Оксани Забужко. Це унікальний жанр діалогу поважних й авторитетних людей на теми, пов'язані $з$ релігійними мотивами у творчості письменника, уперше богослов робить «біблійну екзегезу літературного твору» (Українка 100). Власне, ці розмови і стали об'єктом нашого аналізу.

Мета дослідження - проаналізувати чотири розмови про Лесю Українку Предстоятеля Української греко-католицької церкви Блаженнішого Святослава Шевчука та письменниці Оксани Забужко зі стилістичного погляду, обгрунтувати тезу про новий жанр наукового дискурсу - інтелектуальний діалог.

Матеріал і методи дослідження. Аналізуючи зазначений матеріал, обираємо за метод дослідження лінгвостилістичний аналіз тексту, 3 
допомогою якого виокремлюємо та описуємо основні мовностилістичні ознаки інтелектуального діалогу.

Результати дослідження. На переконання О. Забужко, «після А. Кримського ніхто всерйоз не розглядав Лесю Українку як релігійного мислителя, чиї твори годі поправно відчитати без богословської екзегези» (Українка 9). Попри це останні 12 років життя Лесі Українки - це постійні духовно-релігійні пошуки; «Одержима», якою в 1901 р. починається весь ії «християнський цикл», «до смерті тримає їі в цьому колі проблем» (Українка 29), хоча і в інших творах вона порушувала ці питання («Лісова пісня» - це теж «укрита полеміка з християнством» (Українка 11)). На думку О. Забужко, «оці духовно-релігійні пошуки, пошук своєї релігії» ідуть ще від написаної 1896 року «Блакитної троянди» (Українка 12), а представлені в книзі твори Лесі Українки є «тільки верхівкою айсберга» (Українка 9).

Аналізований нами діалог - це, власне, обмін думками, а не інтерв'ю, хоча тон задає 0.Забужко, яка виступає в ролі інтерв'юєра, однак, на відміну від інтерв'ю, де питання звичайно короткі й чіткі, бо метою $\epsilon$ вислухати того, у кого беруть інтерв'ю, О. Забужко формулює проблеми дуже грунтовно та широко (інколи їі вступні слова сягають кількох сторінок книги (Українка 38-41; 102-104)). Саме письменниця сформувала головні смислові блоки, у які вона згрупувала ті питання, що в неї накопичилися упродовж усього часу роботи над творчістю Лесі Українки.

Вражає багатопластовість і багатоаспектність бесід письменниці та богослова про розуміння i тлумачення аналізованих творів: період раннього християнства - час Лесі Українки - сучасність; прочитання письменницею-філологинею - прочитання богословом найвищого рангу.

Співбесідники тлумачать теми христології (Українчине тлумачення образу Юди, а відтак і Христа з «На полі крові»; культ мучеництва, принесення себе в жертву, особливо жінок у «Руфін і Прісцілла», «Адвокат Мартіан» і відгук цієї проблеми в Небесній сотні); християнства і фемінізму (Святослав Шевчук: «Є певний стереотип - ніби бути покірною нехристиянському ставленню чоловіка до жінки означає бути справжньою християнською жінкою. Ні! Абсолютно ні» (Українка 73)); ідею самотності, яка $є$ екзистенційною темою номер один сучасної культури (Українка 34); роль пророка в суспільстві; проблеми Церкви і родини, сім'ї, обов'язку в стосунку до Церкви і обов'язку в стосунку до родини; тему загубленого українського поганства тощо.

Звичайно, має рацію С. Шевчук, коли каже, що «ми не можемо трактувати Лесю Українку як якогось канонічного екзегета», що «було би цілком хибно читати іiі твори як віроучительний документ, бо це абсолютно різні жанри, кожен із яких ставить перед собою інші мету й інше завдання» (Українка 15), але важливо, як підкреслює Блаженніший, що його «особисто вражає», це «ії постійне бачення в Божому Слові - Слові, яке написане через реальні події, реальну історію, - в історичності тих 
елементів, які є важливими чи й джерельними для християнської віри, певних еталонів. Еталонів, з якими вона себе співвідносить. Еталонів, до яких вона постійно апелює. Еталонів, які вона намагається запитувати, шукаючи відповіді на екзистенційні питання іiі особистого життя, особистого досвіду, а відтак і досвіду життя тогочасного українського суспільства» (Українка 16).

Без сумніву, сприйняття творів на християнську тематику пересічними людьми і професіоналами-богословами дуже різниться. Очевидно, що в теологів виникає чимало таких асоціацій, яких не має пересічний читач. Наприклад, С. Шевчук каже: «Коли я читав її драми, мені спала на думку Книга праведного Йова зі Старого Заповіту. Йов там полемізує, критикує, до певної міри навіть веде війну 3 тогочасним старозавітним богослов'ям, розмовляє зі своїми друзями, які представляють традиційні, усталені канонічні уявлення про релігійне життя тогочасного Ізраїлю» (Українка 16) і продовжує: «Якщо ми в світлі тих інтерпретаційних ключів подивимося на те, що читаємо в Лесі Українки, то побачимо постать Ісуса Христа, якого вона намагається збагнути, відкидаючи ті чи інші догматичні формулювання. 3 одного боку, у віруючих людей це викликає скандал: ну як же ж, це ж абсолютна істина, ця догматична формула, з якою не можна полемізувати, якій можна тільки поклонятися! А Леся каже - ні, поклонятися треба живому Богу, а не нашому уявленню про нього» (Українка 17).

Блаженніший Святослав Шевчук детально пояснює не дуже відому пересічному читачеві історію раннього християнства і лише на цьому тлі аналізує поведінку героїв творів Лесі Українки. Досить несподіваними для співрозмовниці, яка все життя переймається проблемами місця і статусу жінки в сучасному суспільстві, $\epsilon$ висновки Блаженнішого про те, що жінка в біблійній мові - означає спільноту, народ, Церкву (Українка 51), або його ж думка: «Але бути жінкою - це не виконувати суспільну роль, і це не $\epsilon$ щось, що можна в будь-який момент змінити - на протилежну стать, чи на якийсь інший вид гендеру чи сексуальної орієнтації. Це харизма, це дар Божий, велика таємниця особи - бути жінкою, таємниця, яку потрібно відкрити, реалізувати, збагнути. Тому жіноче начало, про яке ми говоримо, на мою думку, в уявленнях Лесі Українки абсолютно відмінне від гендерних теорій нашого часу чи, можливо, навіть від певних інтерпретацій фемінізму другої половини 20-го століття» (Українка 66).

Викликає захоплення манера пояснення Блаженнішим багатьох складних сучасних філософських питань із опертям на відомості 3 етимології, наприклад, про Святий Дух: «Я думаю, що кожен митець переживає натхнення, моменти просвічення, творить найвищі зразки людської культури - завдяки діянню Святого Духа. I справжня культура вона у своїй природі завжди буде духоносна. Саме слово «культура» походить від слова «культивувати», тобто «розвивати». Та культура, яка не плекає, не створює необхідних обставин, необхідного середовища для 
цвітіння людини, $є$ насправді антикультурою - культурою смерті <..>. Але кожна культура для того, щоб бути собою, щоб не перетворюватися на антикультуру, щоб бути середовищем життя, а не смерті, має в найвищім ступені свого розвитку відкритися в культ. Культивувати - культура культ. Чому? Тому що вона буде вести людину до народження, до розвитку життєво важливих органів, потрібних для того, щоб дихати Духом Святим, бачити Бога в обличчя, лицем в лице, щоб бути причасником - вічного життя!» (Українка 64). Ця думка суголосна з ідеями М. Жулинського про те, що, «бажаючи забезпечити неперервність тривання духовних цінностей у цивілізаційному просторі людства, творець культурних цінностей буде пориватися до спілкування з Богом» (Жулинський, «Подих» 8) і що «література, мистецтво покликані і, якщо хочете, приречені відкидати зло і обирати повсякчасно добро, обстоювати природну гідність і цінність людської особистості, відкривати істину про людську особу» (Жулинський, «Християнство» 6).

Звичайно, Леся Українка, як i, напевно, кожна людина, еволюціонувала у своїх поглядах. Згадаймо, як Т. Шевченко в останні роки життя став глибоко християнським поетом, схоже відбувається і з Лесею Українкою. I такий процес С. Шевчук коментує так: «кожна людина, а так само й кожний поет, має свою дорогу. Дорогу, яка має свій початок, свою середину, еволюцію, - і свій кінець: зрілість, апогей, вивершення» (Українка 67). На репліку 0. Забужко, що «Так з дороги ж і збитись можна, перепрошую!», Блаженніший відповідає: «Абсолютно. Так само і віра - це $\epsilon$ дорога. Це дорога до Бога, шлях, який має свій початок, свою еволюцію і свою мету. Тому в певний момент сам Христос казав: «Я дорога, і правда, і життя» (Ів. 14: 6). Ми віримо, що не можна іти тою дорогою, не можна еволюціонувати - народитися, розвиватися, дозріти - без Божого супроводу. I тим Божим супроводом, який дозволяє нам зростати у вірі, і $\epsilon$ Дух Святий, яким Господь Бог нас, сказати б, супроводжує» (Українка 67).

С. Шевчук висновкує, що Леся Українка «є набагато глибше християнською, ніж можна собі на перший погляд уявити» (Українка 100), а О. Забужко констатує, що вона (Леся Українка) «не любила церкви як інституції, це об'єктивний факт і тут нема чого приховувати» (Українка 102). На підтвердження своєї думки О. Забужко наводить цитату із листа Лесі Українки до О. Кобилянської (це «єдиний її віровизнавчий текст», каже 0. Забужко (Українка 115)): «вірю ж я тілько в одного духа, того, що про нього співав Heine в своїй Bergidylle <...>, і з мене тієї віри досить», оця іï відкрито задекларована віра у Святого Духа - це, за великим рахунком, виходить, ця сама одухотворена спільнотність» (Українка 115).

Співбесідники приходять до логічного висновку, що Леся Українка $\epsilon$ апологетом християнства, але християнства не як системи віроучительної, системи абстрактних, логічних утворень, а «християнства як живого богоспілкування» (Українка 17). О. Забужко твердить: «...те, що в нас у радянські часи називалося «атеїзмом Лесі Українки», насправді було ії 
конфліктом із синодальним православ'ям, але це в усіх наших класиків було, і в Шевченка також: «І візантійський Саваоф / Одурить! Не одурить Бог», типова українська антитеза!» (Українка 12-3), тобто «у Лесі Українки було неприйняття інституціоналізованої церкви», а в листі до А. Кримського вона воює з павлініанською традицією (Українка 12).

Дуже цікавою $\epsilon$ мова аналізованих нами діалогів, які $\epsilon$ розшифруванням аудіозаписів розмов С. Шевчука та О. Забужко (чотири рази по дві години), що відбувалися з листопада 2018 по квітень 2019 року в резиденції Глави Української греко-католицької церкви в Києві, ініціатором яких стало видавництво «Комора». Як пише у вступній статті 0. Забужко, «редакція тексту переважно технічна, купюри мінімальні мені залежало на тому, аби якнайдостеменніше донести до читача атмосферу й стиль наших бесід» (Українка 9).

Аналізований текст можемо назвати сучасним інтелектуальним діалогом, який характеризує насамперед надзвичайно високий рівень науковості (із насиченим використанням спеціальної вузькофахової метамови: екзегетична матриця (Українка 15), енігма (Українка 21), гласолалія (Українка 55) тощо, створенням нових термінів: невралгічні моменти християнства, неевклідова геометрія емоцій (Українка 32)), на якому явно позначилися сучасні постмодерні тенденції в літературі.

Одними з основних характеристик постмодернізму, як зауважують дослідники, $є$ «цитація, інтертекстуальність» (Маленко 397), «активне перенесення лексики зі сфери розмовно-побутової до художньої» (Маленко 431), «іронія, гра, цитування, а також змішування жанрів, рівнів мовлення, високої й популярної культури» (Павленко 118), «введення до художнього тексту нового масиву слів іншомовного походження» (Даниленко 18), застосування в нормованому мовленнєвому просторі суржикових, сленгових елементів (Маленко 84) тощо.

Із названих характеристик в аналізованих діалогах найчастіше спостерігаємо:

- інтертекстуальність: окрім, звичайно, творів Лесі Українки, С. Шевчук активно цитує Святе Письмо, твори Отців Церкви, видатних богословів, краківського владику Рися (Українка 28-29) та ін.; 0. Забужко - видатних богословів, філософів, дуже часто відомих діячів сучасності, зокрема згадує Цельса та інших римських філософів (Українка 13), цитує Л.Свідлера (Українка 13), Д. Фоєра (Українка 42), О. Пушкіна (Українка 43), розповідає про фестиваль у Новій Руді, який організовує О. Токарчук і де вона слухала отця Т. Достатнього (Українка 13), про виставу львівського «Театру у кошику» та його режисерку І. Волицьку (Українка 24), про діячку УПА М. Савчук (Українка 42), про В. Винниченка (Українка 46-47) тощо;

- використання висловів різними мовами: С. Шевчук: латинською - de facto (Українка 17; 19; 23; 25 та ін.), martyros (Українка 31); 0. Забужко: латинською - vox populi (Українка 26), Probate spiritus si ex Deo sunt... 
(Українка 54), англійською soft power (Українка 81), польською «Póki my żyjemy» (Українка 98), німецькою - Heine, Bergidylle (Українка 115) тощо;

- різнопластовість лексики: у С. Шевчука знаходимо церковнослов'янські лексеми: сотворіння (Українка 36), сотворений (Українка 43), сопричастя (Українка 59) і нові іншомовні запозичення: християнський меседж (Українка 28; 118), істеблішмент, Йоан - це символ фрілансера (Українка 110), зрідка розмовні слова: о'кей (Українка 32), фразеологізми: мені мороз по шкірі йшов (Українка 85), на злодієві шапка горить (Українка 28) та ін.; в О.Забужко - церковнослов'янські стійкі вислови «Аще хто речеть, яко люблю Бога, а брата свого ненавидить, лож єсть» (Українка 35), поріг, іже не прейдеши (Українка 39), за други своя (Українка 42), персти вложити (Українка 42), однак в її мовленні спостерігаємо дуже багато розмовних складників: шалено цікава тема (Українка 11), життєва заліковка (Українка 10), стрьомно (Українка 28; 49), кошмар (Українка 48), від'юзати (Українка 34), фразеологізми: без сорома казка (Українка 23), аж мурашки по ногах пішли (Українка $37 ; 46)$ тощо;

- використання суржикових, сленгових елементів, хоча все-таки в аналізованому тексті ці засоби виступають не як фрагмент колажу в постмодерністів, а традиційно - для характеристики мовця: О. Забужко більш емоційна, іiї мовлення характеризують більшою мірою розмовні вкраплення: наприклад, суржикізми: вона (Леся Українка. - М. С., М. С.) непроста була «дєвушка» (Українка 100), свій «білєтік» (Українка 19), сленгізми: двічі лузер (про Юду) (Українка 22) тощо; мовлення Блаженнішого більш стримане, логічне, він прагне все виструнчити, упослідовнити;

- наявність розмовних складників (цитуючи Л. Свідлера, О. Забужко каже: «хвилиночку, перевірю ім'я, щоб не помилитися» (Українка 13)); С. Шевчук: «Для Лесі Українки Христос $є$ не ідеєю, а особою (03: (пошепки) Для мене теж!)» (Українка 17); попри високу інтелігентність та вишуканість розмови спостерігаємо інколи захоплене перебивання одне одного із вибаченнями (Маленко 20); у мовленні О. Забужко знаходимо багато вигуків, характерних для розмовного мовлення: o (Українка 25), ой (Українка 23), вау (Українка 21; 23; 27 та ін.), угу (Українка 21; 32), браво (Українка 23), ух ти (Українка 38) тощо;

- поєднання надзвичайно серйозного i жартівливого (інколи іронічного): О. Забужко: «а що врешті обоє гинуть (у „Лісовій пісні”. - M. С., M. C.), ну так чи ж християн цим лякати? Так? (Сміється). Це фактично хепіенд, така смерть» (Українка 12); С. Шевчук: «...до певної міри той образ Юди, який малює наша авторка, - це образ людини, яка вірить, що без неї Бог не може обійтись. О Боже, дивися - ну як Ти без мене можеш звершити свою місію? - 03: (сміється) Шикарно!» (Українка 19). Так само трактуємо реакцію Блаженнішого сміхом (який редактори подають як ремарку), коли ще на початку їхньої розмови О. Забужко вже говорить про те, що поляки обіцяли перекласти їхні розмови (Українка 14) та ін. 
Спостерігаємо інколи дещо штучне, на наш погляд, заниження О. Забужко свого рівня знань перед Главою Церкви, абсольвентом i доктором Папського університету святого Томи Аквінського в Римі та глибоким знавцем богослов'я: мій агностично школений «хлопський розум» (Українка 11), перепрошую наперед за своє екзегетичне невігластво, я ж, так би мовити, тупий лаїк (Українка 20) тощо. Але безсумнівно, обоє співбесідників настільки глибоко прониклися проблемами творів Лесі Українки, що сама О. Забужко каже з цього приводу Блаженнішому: «так само, як я крізь текст бачу, відчуваю Лесю Українку, яка його писала, - так ви відчуваєте священика, який міг би це прочитати» (Українка 28). Захоплення співрозмовників розглядуваними проблемами і названі вище мовностилістичні риси діалогу роблять високоінтелектуальний текст надзвичайно цікавим для читача, таким, від якого важко відірватися.

Редакторка Г. Гаджилова пише: «останній цитований уривок із «Руфін і Прісцілла» наводить на думку, що питання християнства турбували Лесю Українку, серед іншого, у контексті його впливу на майбутнє всього людства загалом і їі рідної України зокрема» (132). I справді, Леся Українка порушує питання, які є надзвичайно актуальними й сьогодні.

У працях, присвячених постмодерністській літературі, звичайно наголошують на тому, що ця література, всупереч наріканням на вживання ненормативної лексики, текстовий і сюжетний хаос, $\epsilon$ «надзвичайно інтелектуальною і розрахована на високоінтелектуального читача 3 аналітично-творчим мисленням, вимагає від нього не тільки знання різногалузевої наукової термінології, іноземних мов і художніх творів, але й самостійного осмислення прочитаного та долучення до процесу текстотворення» (Мартакова 175). Це стосується й аналізованого нами тексту. Як пише у вступній статті О.Забужко, вона під час цих бесід відчувала «радість інтелектуального сп'яніння, радість своєї причетності, чи, за словами Блаженнішого, «сопричастя» тій високій культурі, в якій відбувається ця екзегеза» (Українка 10).

Висновки й перспективи дослідження. Отже, О. Забужко і С. Шевчук не лише запропонували певні ключі для розшифрування ідей Лесі Українки, але й, думаємо, цими розмовами започаткували новий жанр наукового дискурсу - інтелектуальний діалог, у якому ведуть поважну фахову й грунтовну розмову про актуальні проблеми сучасності з унікальним поєднанням науковості та сучасного розкутого мовного оформлення.

\section{Список використаної літератури}

Антофійчук, Володимир. «Християнський контекст творчості Лесі Українки». Народознавчі зошити, № 1-2, 2009, с. 225-9.

Антофійчук, Володимир. Християнські ідеї та образи в творчості Лесі Украӥнки. Чернівці: Рута, 2002. 
Бетко, Ірина. «Біблійні мотиви творчості Лесі Українки в європейському контексті». Українська література в системі літератур Європи і Америки (ХIX-XX ст.). Київ: Заповіт, 1997, с. 136-51.

Бетко, Ірина. «Біблія як джерело ідей у творчості Лесі Українки (Проблемний огляд)». Слово і час, № 3, 1991, с. 28-36.

Гаджилова, Ганна. «Передмова наукової редакторки». Леся Украӥнка. Апокриф / Блаженніший Святослав Шевчук, Оксана Забужко. Чотири розмови про Лесю Українку. Київ: Видавничий дім «Комора», 2020, с. 127-32.

Гребенюк, Віктор. Леся Українка. Що дасть нам силу? Твори на біблійні теми та переклади зі Святого Письма. Луцьк: Ключі, 2011.

Даниленко, Лідія. «У пошуках віртуальної дійсності (Стилістичне розв’язання проблеми мовної фальші в малій українській прозі 80-90-х рр. ХХ ст.)». Слово і час, № 4-5, 1999 , с. $15-8$.

Жулинський, Микола. «Подих третього тисячоліття. Українська література на межі тисячоліть». Біблія і культура, вип. 2, 2000, с. 5-12.

Жулинський, Микола. «Християнство і національна культура». Біблія і культура, вип. 1, 2000, c. 6-8.

Загребельний, Ігор. Християнство і ритми цивілізації: релігійно-історіософська проблематика у творчості Лесі Українки. URL: https://www.religion.in.ua/main/ 11201-xristiyanstvo-i-ritmi-civilizaciyi-religijno-istoriosofska-problematika-utvorchosti-lesi-ukrayinki-chastina-i.html

Заїка 0. «Творче переосмислення біблійних сюжетів, образів як особливість поетики Лесі Українки». Роль християнства в утвердженні освіти, науки та мистещтва: історія, уроки, перспективи. Рівне, 2000, с. 194-8.

Корнейчик, Ігор. «Атеїзм Лесі Українки». Наука і життя, № 3, 1958.

Маленко, Олена. Лінгво-естетична інтерпретація буття в українській поетичній мовотворчості (від фольклору до постмодерну). Харків: Харківське історикофілологічне товариство, 2010.

Мартакова, Анна. «Мовна гра: фонетична організація постмодерного поетичного тексту». Лінгвістичні дослідження, вип. 48, 2018, с. 174-7.

Мизак, Нестор, і Яремчук, Андрій. «Біблійна символіка у творчості Лесі Українки». Релігія та Соціум, № 3-4 (27-28), 2017, с. 79-87.

Мороз, Лариса. «Леся Українка і християнство». Дивослово, № 2, 1995, с. 4-10.

Павлишин, Марко. «Українська культура з погляду постмодернізму». Сучасність, № 5, 1992, c. 117-21.

Українка, Леся. Апокриф / Блаженніший Святослав Шевчук, Оксана Забужко. Чотири розмови про Лесю Українку. Київ: Видавничий дім «Комора», 2020.

\section{References}

Antofiychuk, Volodymyr. "On Christian Context of Lesya Ukrainka's Creative Work". The Ethnology Notebooks, no. 1-2, 2009, pp. 225-9.

Antofiichuk, Volodymyr. Khrystyianski idei ta obrazy v tvorchosti Lesi Ukrainky. Chernivtsi: Ruta, 2002.

Betko, Iryna. "Bibliini motyvy tvorchosti Lesi Ukrainky v yevropeiskomu konteksti”. Ukrainska literatura v systemi literatur Yevropy i Ameryky (XIX-XX st.). Kyiv: Zapovit, 1997, pp. $136-51$.

Betko, Iryna. "Bibliia yak dzherelo idei u tvorchosti Lesi Ukrainky (Problemnyi ohliad)". Slovo $i$ Chas, no. 3, 1991, pp. 28-36.

Hadzhylova, Hanna. Peredmova naukovoi redaktorky. Lesia Ukrainka. Apokryf / Blazhennishyi Sviatoslav Shevchuk, Oksana Zabuzhko. Chotyry rozmovy pro Lesiu Ukrainku. Kyiv: Vydavnychyi dim "Komora", 2020, pp. 127-32.

Hrebeniuk, Viktor. Lesia Ukrainka. Shcho dast nam sylu? Tvory na bibliini temy ta pereklady zi Sviatoho Pysma. Lutsk: Kliuchi, 2011. 
Danylenko, Lydya. "U poshukakh virtualnoi diisnosti (Stylistychne rozviazannia problemy movnoi falshi v malii ukrainskii prozi 80-90-kh rr. XX st.)”. Slovo i Chas, no. 4-5, 1999, pp. 15-8.

Zhulynskyi, Mykola. "Podykh tretoho tysiacholittia. Ukrainska literatura na mezhi tysiacholit". Bibliia i kultura, iss. 2, 2000, pp.5-12.

Zhulynskyi, Mykola. "Khrystyianstvo i natsionalna kultura". Bibliia i kultura, iss. 1, 2000, pp.6-8.

Zahrebelnyi, Ihor. Khrystyianstvo i rytmy tsyvilizatsii: relihiino-istoriosofska problematyka $u$ tvorchosti Lesi Ukrainky. www.religion.in.ua/main/11201-xristiyanstvo-i-ritmicivilizaciyi-religijno-istoriosofska-problematika-u-tvorchosti-lesi-ukrayinki-chastinai.html

Zaika, 0. "Tvorche pereosmyslennia bibliinykh siuzhetiv, obraziv yak osoblyvist poetyky Lesi Ukrainky". Rol khrystyianstva $v$ utverdzhenni osvity, nauky ta mystetstva: istoriia, uroky, perspektyvy. Rivne, 2000, pp. 194-8.

Korneichyk, Igor. "Ateizm Lesi Ukrainky“. Nauka i zhyttia, no. 3, 1958.

Malenko, Olena. Linhvo-estetychna interpretatsiia buttia v ukrainskii poetychnii movotvorchosti (vid folkloru do postmodernu). Kharkiv: Kharkivske istoryko-filolohichne tovarystvo, 2010.

Martakova, Anna. "Linguistic Game: Phonetic Organization of Postmodern Poetic Text". Lingvistichni doslidzhennja, iss. 48, 2018, pp. 174-7.

Myzak, Nestor, i Yaremchuk, Andrii. "Biblical symbols in the works of Lesia Ukrainka". Religion and Socium, no. 3-4 (27-28), 2017, pp. 79-87.

Moroz, Larysa. "Lesia Ukrainka i khrystyianstvo". Dyvoslovo, no. 2, 1995, pp. 4-10.

Pavlyshyn, Marko. "Ukrainska kultura z pohliadu postmodernizmu”. Suchasnist, no. 5, 1992, pp. 117-21.

Ukrainka, Lesia. Apokryf / Blazhennishyi Sviatoslav Shevchuk, Oksana Zabuzhko. Chotyry rozmovy pro Lesiu Ukrainku. Kyiv: Vydavnychyi dim "Komora", 2020.

Стаття надійшла до редколегії 21.02.2021 